Prepared in cooperation with

the U.S. Agency for International Development and the U.S. Army Corps of Engineers

Groundwater-Level Trends and Forecasts, and Salinity Trends, in the Azraq, Dead Sea, Hammad, Jordan Side Valleys, Yarmouk, and Zarqa Groundwater Basins, Jordan

Executive Summary for Open-File Report 2013-1061

U.S. Department of the Interior U.S. Geological Survey 
Cover. Wadi Mujib near the Dead Sea, Jordan. Photo by Daniel J. Goode, U.S. Geological Survey. 


\section{Groundwater-Level Trends and Forecasts, and Salinity Trends, in the Azraq, Dead Sea, Hammad, Jordan Side Valleys, Yarmouk, and Zarqa Groundwater Basins, Jordan}

Open-File Report 2013-1061

By Daniel J. Goode, Lisa A. Senior, Ali Subah, and Ayman Jaber*

*Hashemite Kingdom of Jordan, Ministry of Water and Irrigation

\section{Executive Summary}

\section{Introduction}

The U.S. Agency for International Development (USAID) is providing water-resources management support to Jordan. According to USAID (2010),

Jordan is one of the ten most water-deprived countries in the world. Lack of water will be one of the most serious challenges to Jordan's future economic growth and stability. With population expected to double by 2029, the already low availability will be halved. USAID's water portfolio activities are designed to enhance Jordan's ability to manage its water resources wisely as well as in a more integrated and efficient manner. This helps support regional stability as it prevents conflict, provides quality water for the population and improves the overall economic prospects for the country. Specific activities are initiated in partnership with the Government of Jordan (GOJ) and focus on: improving environmental protection; optimizing the availability and use of water resources, strengthening water policies and systems, and improving resource allocation. 
The U.S. Geological Survey (USGS) and Hashemite Kingdom of Jordan, Ministry of Water and Irrigation (MWI) evaluated groundwater-level and salinity trends in Jordan in cooperation with USAID and the U.S. Army Corps of Engineers in order to

- Update a 2002 USGS groundwater-trends study (David W. Clark, USGS, written commun., 2002);

- Inform USAID's 5-year strategic plan,

- Evaluate trends by using all available data from the MWI;

- Transfer trends estimation technology to MWI staff; and

- Provide scientific information and tools that can be used to

- Identify a time horizon for groundwater-management planning,

- Prioritize locations for groundwater-management actions,

- Provide a baseline for evaluating the effects of the reduction in withdrawals planned to start in 2014,

○ Help quality assure (QA) the data,

- Improve groundwater-model calibration,

- Evaluate corresponding increases in groundwater-supply costs (Rosenberg and Peralta, 2011), and

- Increase public and stakeholder awareness of groundwater trends.

Groundwater levels, salinity, and related information collected by the MWI from 1960 through early 2011 were retrieved and compiled from MWI's Water Information System (WIS) database in March 2011. Where data were available, trends in the groundwater levels and salinity (electrical conductivity) were estimated for individual wells. Water-level and salinity data for six groundwater basins in Jordan-Azraq, Dead Sea, Hammad, Jordan Side Valleys, Yarmouk, and Zarqa — were evaluated. (The Zarqa groundwater basin is also referred to as "Amman-Zarqa." The Jordan Side Valleys basin is distinct from the Jordan Valley, and is also referred to as "Side Wadis" or "Rift Valley Side Wadis.")

\section{Water-Level Trends and Forecasts}

Long-term groundwater-level trends were estimated by use of ordinary least squares linear regression (Helsel and Hirsch, 2002) for all available data. In addition, the trend in 2010 was estimated by graphical linear fits to several years of recent data. Trends were not estimated for wells with fewer than six measurements separated in time, or with less than four years of data. Groundwater-level trends in 2010 were estimated for only 117 wells with data in 2009 or later. Apparent data outliers were occasionally observed but were not corrected except in a few extreme cases. Groundwater levels were forecast to 2030 by extrapolating the 2010 trends. For the forecasts made by linear extrapolation, it was assumed that the factors controlling trends in 2010 will continue unchanged in the future. Where aquifer data were available, the saturated thickness in 2030 was evaluated from the trend forecast. The saturated thickness is a simple measure of the amount of water stored in the aquifer. The forecast aquifer saturated thickness is reported as a percent of total aquifer thickness or maximum observed saturated thickness during the period of record. An example hydrograph for trend estimation and forecast of saturated thickness is shown in figure ES-1. 


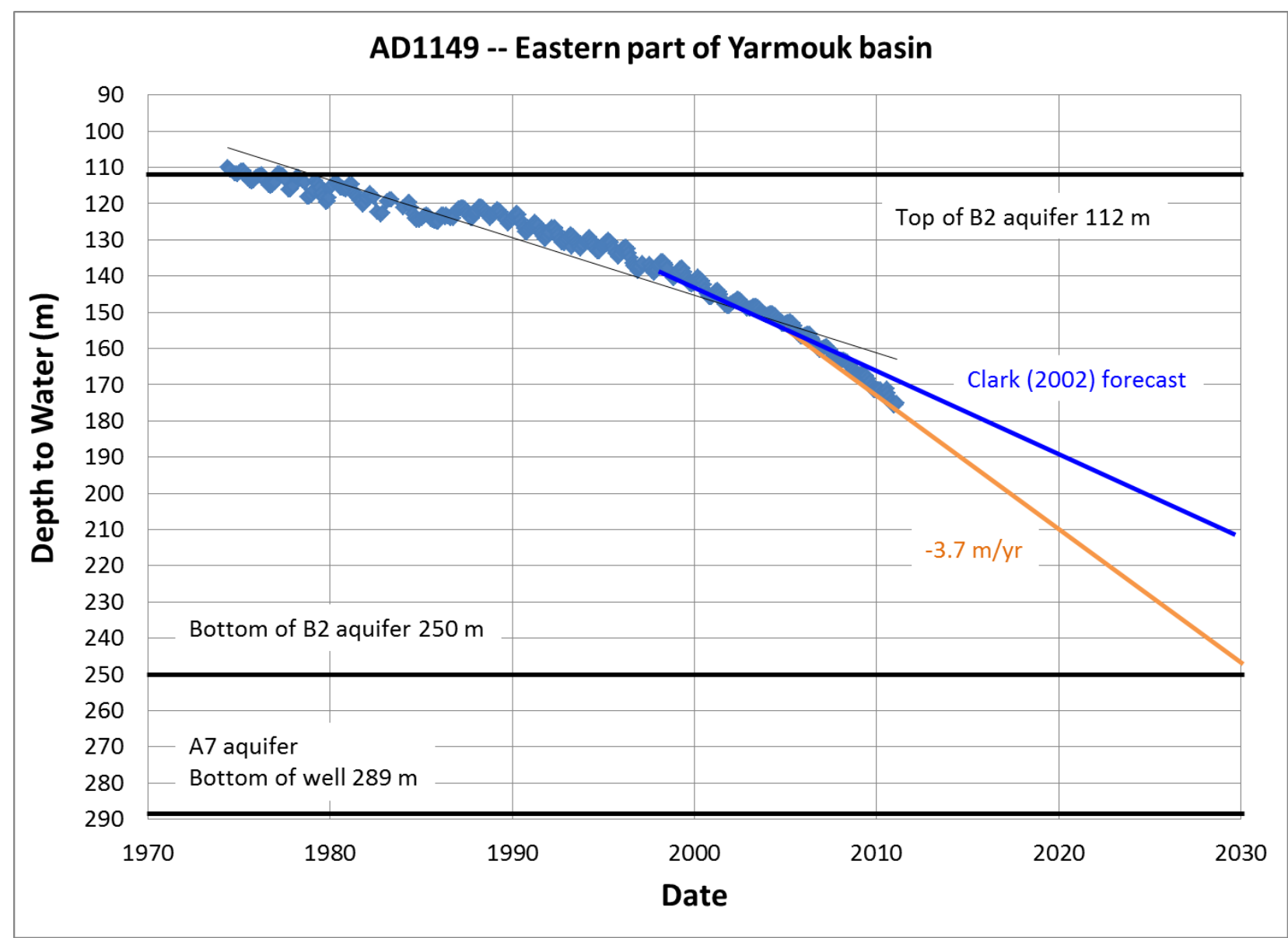

Figure ES-1. Groundwater hydrograph showing water levels and trend lines for well AD1149 in the Yarmouk groundwater basin, Jordan. The thin gray line is the long-term trend by ordinary least squares linear regression to all available data. The blue line is the graphical trend and forecast of Clark (2002). The orange line is the trend in 2010 extrapolated to forecast the depth to water and aquifer saturated thickness in 2030. (Data provided by Ministry of Water and Irrigation, Jordan; m, meters; yr, year; Clark (2002), David W. Clark, U.S. Geological Survey, written commun., 2002)

The groundwater-level trend in 2010, averaged for each basin, ranged from 0 to -1.9 meters per year (m/yr) (table ES-1). Four of the six basins had an average trend close to $-1 \mathrm{~m} / \mathrm{yr}$, yielding a forecast average water-level decline of about 20 meters by 2030 in these basins. The Hammad basin had no trend, on average, and the average water-level decline was fastest in the Jordan Side Valleys basin, at $-1.9 \mathrm{~m} / \mathrm{yr}$; thus, the forecast average water-level decline in this basin was about 38 meters by 2030 . The maximum trend in 2010 at an individual well in each basin ranged from -0.2 to $-9 \mathrm{~m} / \mathrm{yr}$. The forecast average saturated thickness in 2030 ranged from 61 to 98 percent. The average saturated thickness was forecast to remain relatively unchanged in the Hammad basin, whereas all other basins were forecast to have substantial declines in saturated thickness. Some locations in three of the basins were forecast to have zero saturated thickness by 2030 . 
Table ES-1. Summary of groundwater-level trends and forecast saturated thicknesses in six groundwater basins, Jordan.

\begin{tabular}{|l|c|c|c|c|c|c|}
\hline $\begin{array}{c}\text { Groundwater } \\
\text { basin }\end{array}$ & $\begin{array}{c}\text { Number } \\
\text { of wells }\end{array}$ & \multicolumn{2}{|c|}{$\begin{array}{c}\text { Groundwater level trend } \\
\text { 2010 } \\
\text { (meters per year) }\end{array}$} & \multicolumn{2}{|c|}{$\begin{array}{c}\text { Forecast 2030 } \\
\text { saturated thickness } \\
\text { (percent) }\end{array}$} & $\begin{array}{c}\text { Number of } \\
\text { wells dry } \\
\text { in 2030 }\end{array}$ \\
\hline Azraq & & Average & Maximum & Average & Minimum & \\
\hline Dead Sea & 15 & -0.8 & -2.3 & 69 & 14 & 0 \\
\hline Hammad & 30 & -0.8 & -9 & 61 & 0 & 3 \\
\hline Jordan Side Valleys & 4 & 0 & -0.2 & 98 & 93 & 0 \\
\hline Yarmouk & 9 & -1.9 & -9 & 64 & 20 & 0 \\
\hline Zarqa & 11 & -1.1 & -3.7 & 66 & 0 & 1 \\
\hline
\end{tabular}

Groundwater levels were declining in most wells in Jordan (fig. ES-2; Hammad basin is not shown. See the section on Hammad water levels in the main report). The largest rates of decline occurred near major pumping centers. Trends were variable in that wells with rapid declines are located near wells with modest declines, no trends, or small rises. These differences may be related to the different depths or aquifers that the wells penetrate, but these local conditions were not explored in this study. Adequate data were not available to evaluate the groundwater-level trends in some areas of heavy pumping, such as the eastern parts of the Yarmouk and Zarqa basins (fig. ES-2).

Aquifer saturated thickness in 2030 was forecast to drop below 25 percent of historic or total thickness in many locations in Jordan (table ES-1; fig. ES-3; Hammad basin is not shown. See the section on Hammad water levels in the main report). For this forecast, it was assumed that the conditions controlling the trend in 2010, primarily pumping and recharge rates, do not change. 


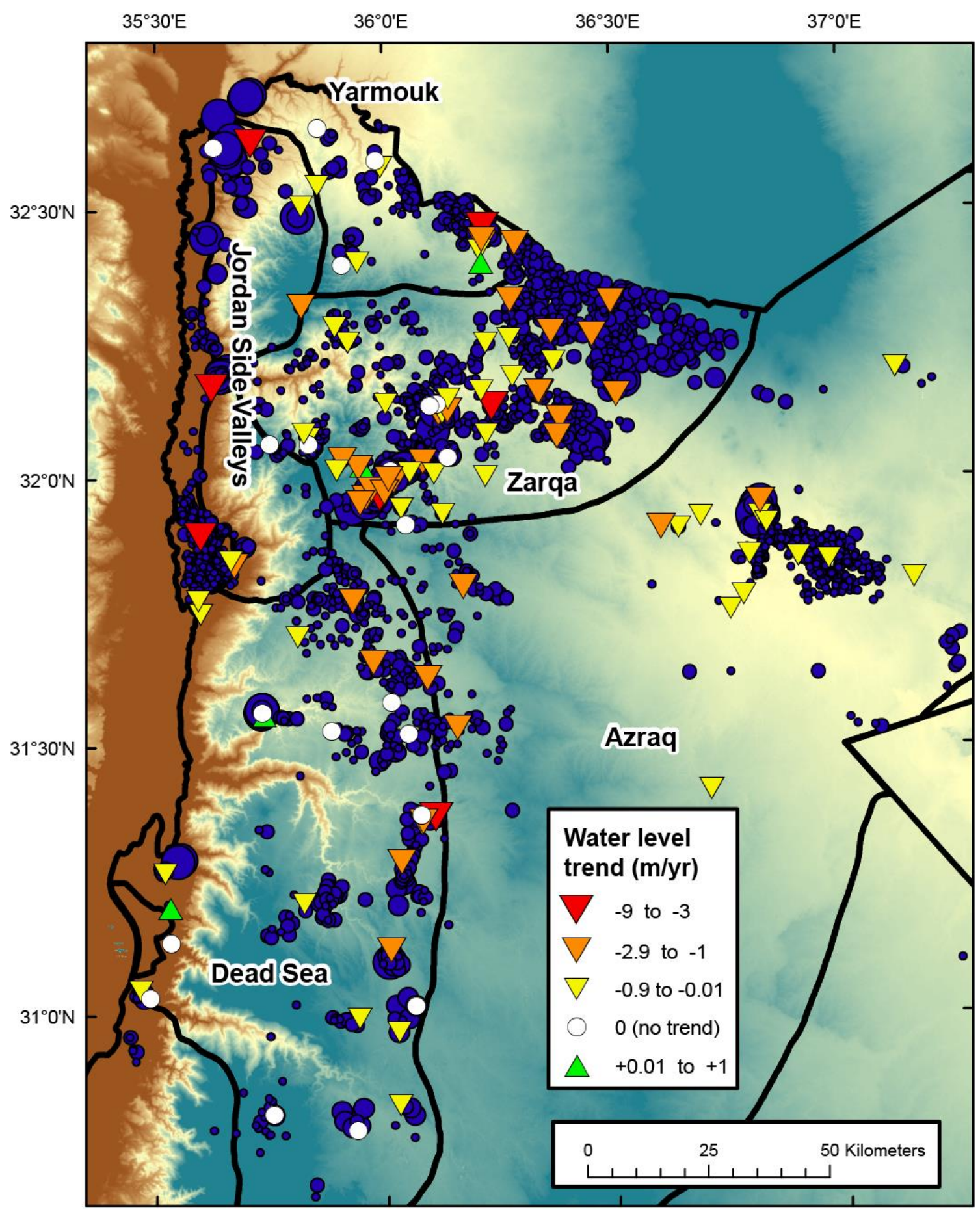

Figure ES-2. Trends in groundwater levels at selected wells in Jordan. The background colors represent land-surface altitude in meters, ranging from lower than 0 (brown) to higher than 1000 (blue). The groundwater-level trend in 2010, in meters per year, is shown for all wells with data in 2009 or later. Negative trends indicate declining water levels. The dark-blue dots are production wells, and the size of the dot represents the annual withdrawal from each well in 2009. (Base map and all data provided by Ministry of Water and Irrigation, Jordan; Projection is Palestine 1923 Palestine Belt, Transverse Mercator; m/yr, meters per year) 


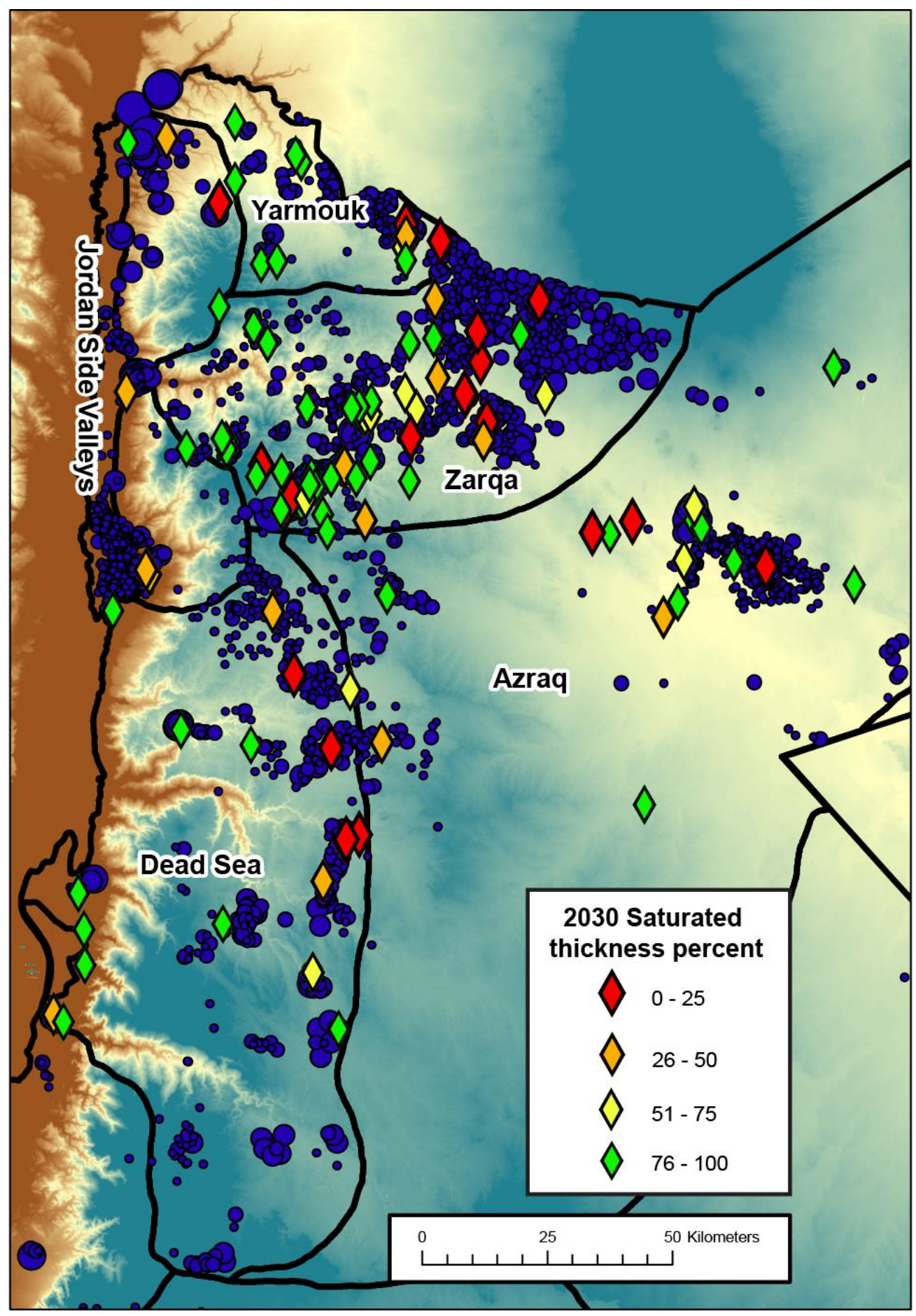

Figure ES-3. Forecast saturated aquifer thickness in 2030 at selected wells in Jordan. The background colors represent land-surface altitude in meters, ranging from lower than 0 (brown) to higher than 1000 (blue). The forecast saturated thickness in 2030, as a percent (0-100) of total or maximum saturated thickness, is shown for all wells with data in 2009 or later and with aquifer information. The dark-blue dots are production wells, and the size of the dot represents the annual withdrawal from each well in 2009. (Data provided by Ministry of Water and Irrigation, Jordan) 


\section{Key findings - Groundwater levels}

Data quality was very good, but monitoring data were not available for some areas.

$\square$ Groundwater levels continued to decline about $-1 \mathrm{~m} / \mathrm{yr}$ in groundwater basins with large withdrawals.

In most cases, rates of decline were constant or increasing (faster decline).

If these rates of decline continue, average saturated aquifer thicknesses were forecast to decline by 30 to 40 percent by 2030 .

Saturated aquifer thickness was forecast to be zero by 2030 in 5 percent of the locations evaluated.

$\square$ Some shallow wells that do not fully penetrate the aquifer will likely go dry, and go dry more frequently where rates of decline are increasing.

Less water is stored in aquifers in Jordan as groundwater levels decline. 


\section{Salinity trends}

Salinity trends in groundwater were evaluated by using electrical conductivity (EC) data from MWI's WIS database; data were retrieved and compiled in March 2011. EC is generally correlated with total dissolved solids (or salinity) in natural waters. Salinity reflects the generation and transport of dissolved constituents in water and can be spatially variable in groundwater, depending on sample location in the flow field relative to recharge and discharge areas. Salinity generally increases substantially with depth, as deeper waters have long residence times to accumulate dissolved salts from aquifer rocks. Salameh (1996) identifies an EC of 1,500 microsiemens per centimeter $(\mu \mathrm{S} / \mathrm{cm})$ as an upper limit of freshwater suitable for all common uses in Jordan. Long-term EC trends were estimated by ordinary least squares linear regression for all available data. Separate trends in 2010 and forecasts were not evaluated because of the high variability of the data. Trends were not estimated for wells with less than six measurements separated in time, or with less than 4 years of data. Groundwater EC trends were estimated for only 205 wells with data for 2009 or later, or for Azraq, Hammad, and Jordan Side Valleys basins for 2006 or later. The statistics and maps were developed from data as provided from WIS. Apparent data outliers were occasionally observed but were not corrected, except in a few extreme cases. An example EC graph for trend estimation is shown in figure ES-4.

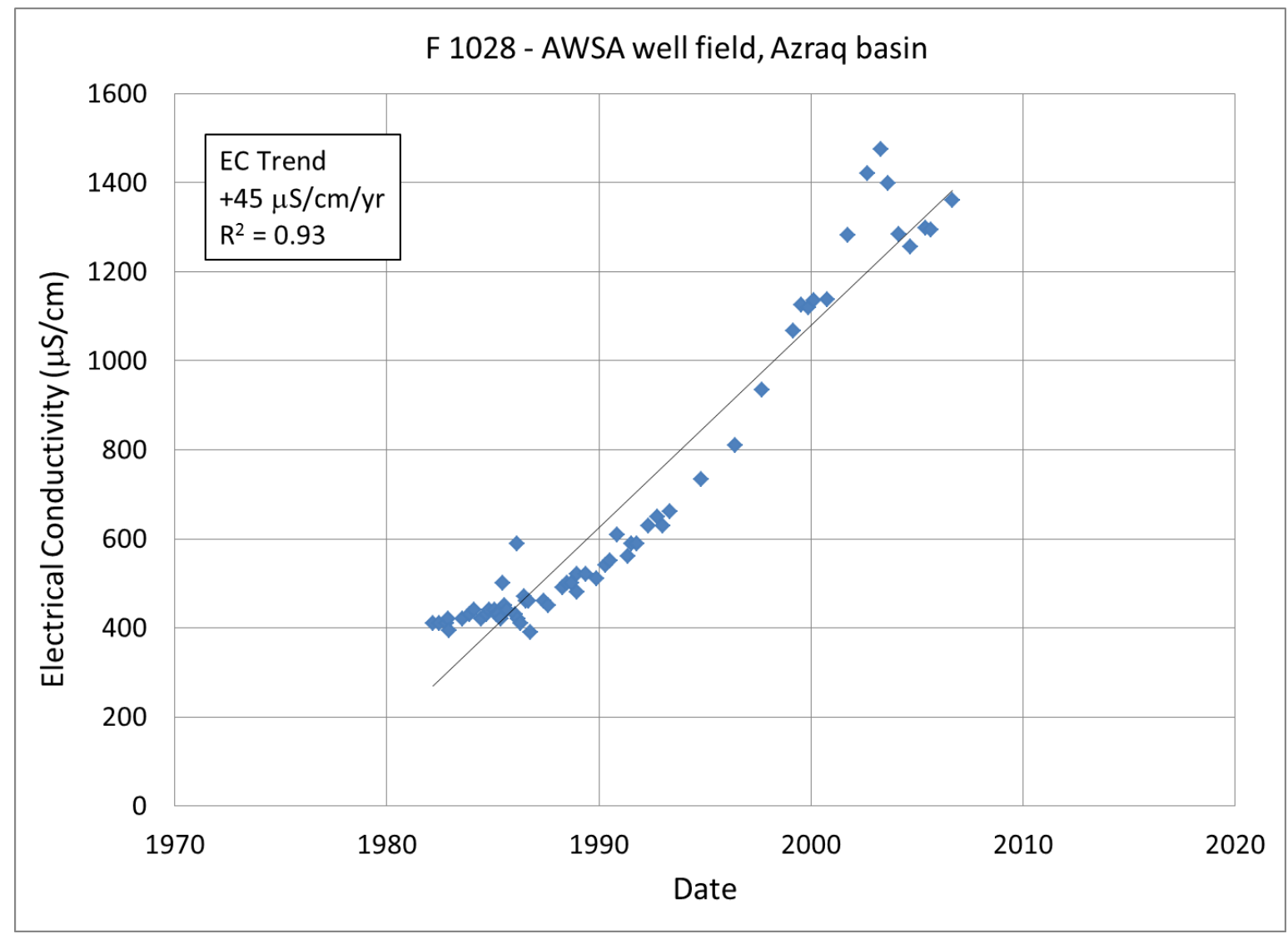

Figure ES-4. Groundwater electrical conductivity (EC) and trend line for well F 1028 in the Azraq groundwater basin, Jordan. The long-term trend is determined by ordinary least squares linear regression to all available data. (Data provided by Ministry of Water and Irrigation, Jordan; $\mu \mathrm{S} / \mathrm{cm}$, microsiemens per centimeter; yr, year; $\mathrm{R}^{2}$, coefficient of determination) 
The long-term linear trend in groundwater EC, averaged by basin, ranged from -2.8 to +27 $\mu \mathrm{S} / \mathrm{cm} / \mathrm{yr}$ (table ES-2). The Jordan Side Valleys basin was the only basin with an average decrease in EC. A trend of $+/-5 \mu \mathrm{S} / \mathrm{cm} / \mathrm{yr}$ is considered flat (no substantial trend) for summary purposes. The proportion of wells where EC was increasing more than $+5 \mu \mathrm{S} / \mathrm{cm} / \mathrm{yr}$ ranges from 19 to 66 percent, with the highest percentage in the arid Hammad basin. (Note that groundwater levels are not declining rapidly in the Hammad basin, and only six wells had current EC data.) The heavily pumped Zarqa basin had many wells with current EC data, had the second highest current EC, and had the second highest average rate of EC increase; the EC trend was greater than $+5 \mu \mathrm{S} / \mathrm{cm} / \mathrm{yr}$ for 58 percent of the wells evaluated.

Table ES-2. Summary of groundwater electrical conductivity trends in six groundwater basins, Jordan. $[\mu \mathrm{S} / \mathrm{cm}$, microsiemens per centimeter; yr, year; \%, percent]

\begin{tabular}{|c|c|c|c|c|c|}
\hline \multirow[t]{2}{*}{ Groundwater basin } & \multirow[t]{2}{*}{$\begin{array}{l}\text { Number } \\
\text { of wells }\end{array}$} & \multirow{2}{*}{ 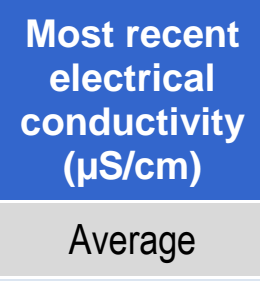 } & \multirow{2}{*}{$\begin{array}{l}\text { Long-term } \\
\text { linear trend } \\
\text { ( } \mu \mathrm{S} / \mathrm{cm} / \mathrm{yr} \text { ) }\end{array}$} & \multicolumn{2}{|c|}{$\begin{array}{c}\text { Percentage of } \\
\text { wells with trend } \\
\text { greater than } \\
+/-5 \mu \mathrm{S} / \mathrm{cm} / \mathrm{yr}\end{array}$} \\
\hline & & & & $\%+$ & $\%-$ \\
\hline Azraq & 25 & 1290 & +27 & 26 & 20 \\
\hline Dead Sea & 28 & 1180 & +10.5 & 43 & 25 \\
\hline Hammad & 6 & 1590 & +4.9 & 66 & 16 \\
\hline Jordan Side Valleys & 24 & 989 & -2.8 & 19 & 25 \\
\hline Yarmouk & 16 & 990 & +3.5 & 19 & 19 \\
\hline Zarqa & 106 & 1487 & +16 & 58 & 14 \\
\hline
\end{tabular}

Groundwater EC trends were highly variable in Jordan (fig. ES-5; Hammad basin is not shown. See the section on Hammad EC trends in the main report). Most wells with rapidly increasing EC are located at lower altitudes in the basins in discharge areas, away from freshwater recharge. As noted by Salameh (1996), "Generally, the water salinity increases in the direction of groundwater flow, from the areas adjacent to the recharge areas to the discharge areas." For example, EC trends were rapidly increasing in the central part of the Zarqa basin and the oasis area of the Azraq basin. Likewise, a few wells near the Dead Sea showed large increasing trends. Trends were variable in that wells with rapid increases are located near wells with flat or decreasing EC trends. These differences may be related to the different depths or aquifers that the wells penetrate, but these local conditions were not explored in this study. Salinity may also be affected by local irrigation and wastewater leakage. Data were not available to evaluate the current groundwater EC trend in some areas of pumping (fig. ES-4). 


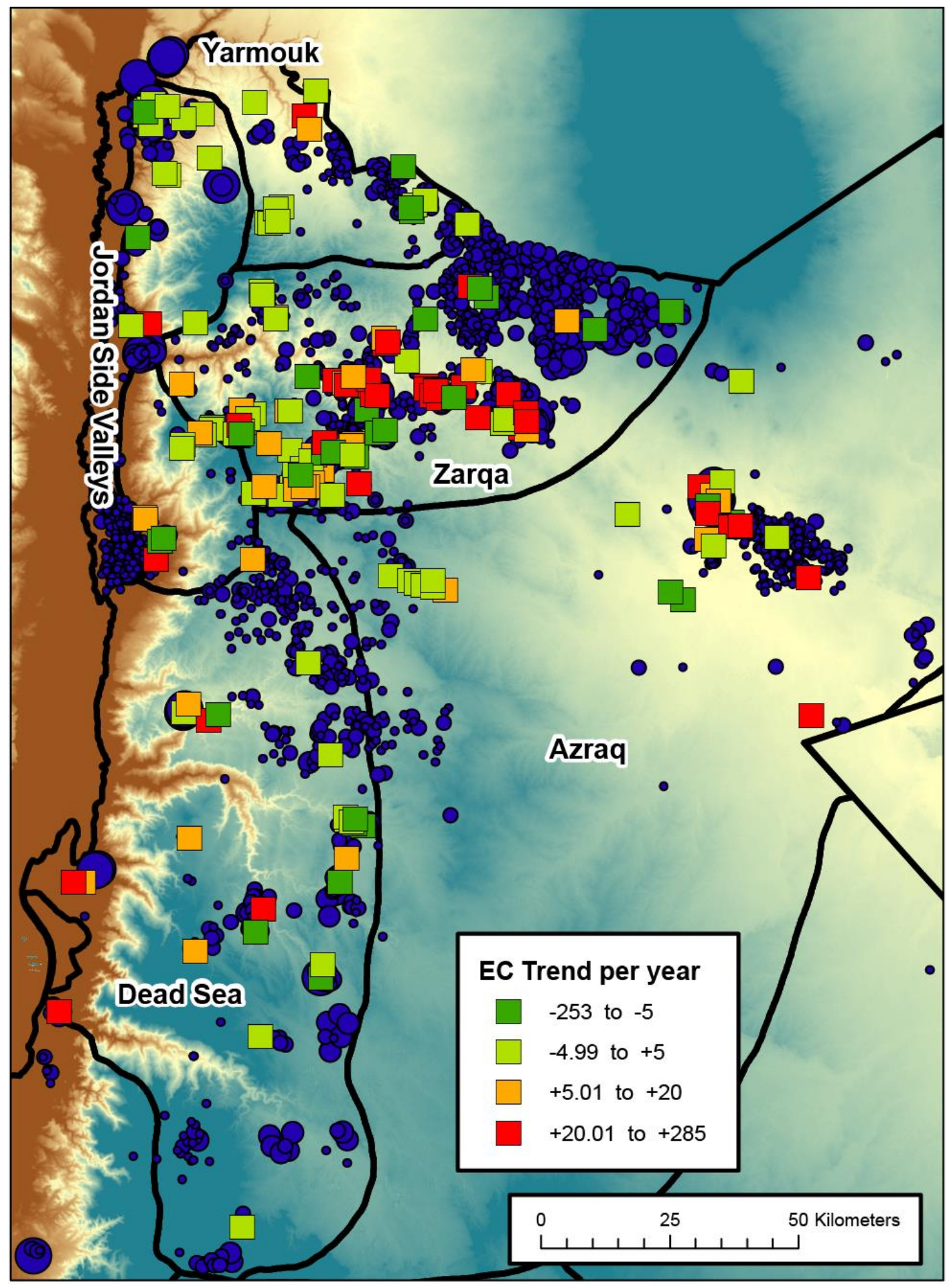

Figure ES-5. Trends in groundwater electrical conductivity (EC) in Jordan. The background colors represent landsurface altitude in meters, from lower than 0 (brown) to higher than 1000 (blue). The long-term EC trend, in microsiemens per centimeter per year, is shown for all wells with data in 2009 (2006 in Azraq and Jordan Side Valleys) or later. The dark-blue dots are production wells, and the size of the dot represents the annual withdrawal from each well in 2009. (Data provided by Ministry of Water and Irrigation, Jordan) 


\section{Key findings - Groundwater salinity}

Salinity data were much more variable and sparse than water-level data, thus the estimated trends have high uncertainty.

Salinity was not increasing rapidly in most wells, except in Zarqa and Hammad basins.

Salinity was increasing in lower parts of basins, in discharge areas, and generally near heavy withdrawals.

Changes in pumping patterns or blending necessitated by salinity will likely occur more frequently in the future where salinity is increasing.

Water-level declines did not necessarily imply salinity increases; geologic setting, amount of recharge, and position relative to recharge and discharge areas were important factors in determining high salinity and increasing trends.

Less freshwater will be available from aquifers in Jordan as groundwater salinity increases.

\section{Acknowledgments}

The authors are grateful for the technical guidance and support of Maysoon Zoubi, former Secretary General of the Ministry of Water and Irrigation (MWI), Jordan. We are also grateful for technical background information and data provided by Tobias El-Fahem and Ibraheem Hamdan of the MWI/Bundesanstalt für Geowissenschaften und Rohstoffe (BGR) Water Aspects in Landuse Planning project. Ali Breazat and Ali Hayajneh of the MWI contributed to groundwater-level trends analysis for wells in Azraq basin. Linda Zarr, USGS, contributed to data analysis. The report was reviewed by Michaela Johnson, Dennis Low, and Ruth Larkins, USGS.

\section{References Cited}

Helsel, D.R. and R. M. Hirsch, 2002, Statistical Methods in Water Resources: Techniques of Water Resources Investigations, Book 4, chapter A3, U.S. Geological Survey, 522 p.

Rosenberg, D.E., and Peralta, Richard, 2011, Economic impacts of groundwater drawdown in Jordan: Amman, Jordan, International Resources Group report for USAID contract EPP-I-00-04-00024-00, $29 \mathrm{p}$.

Salameh, Elias, 1996, Water quality degradation in Jordan (Impacts on environment, economy and future generations resources base): Friedrich Ebert Stiftung, Amman, Jordan, 179 p.

U.S. Agency for International Development, 2010, USAID in Jordan, Water Resources Management: accessed online December 9, 2010 at http://jordan.usaid.gov/sectors.cfm? inSector $=16$. 

For additional information:

Director

U.S. Geological Survey

Pennsylvania Water Science Center

215 Limekiln Road

New Cumberland, PA 17070

http://pa.water.usgs.gov/ 


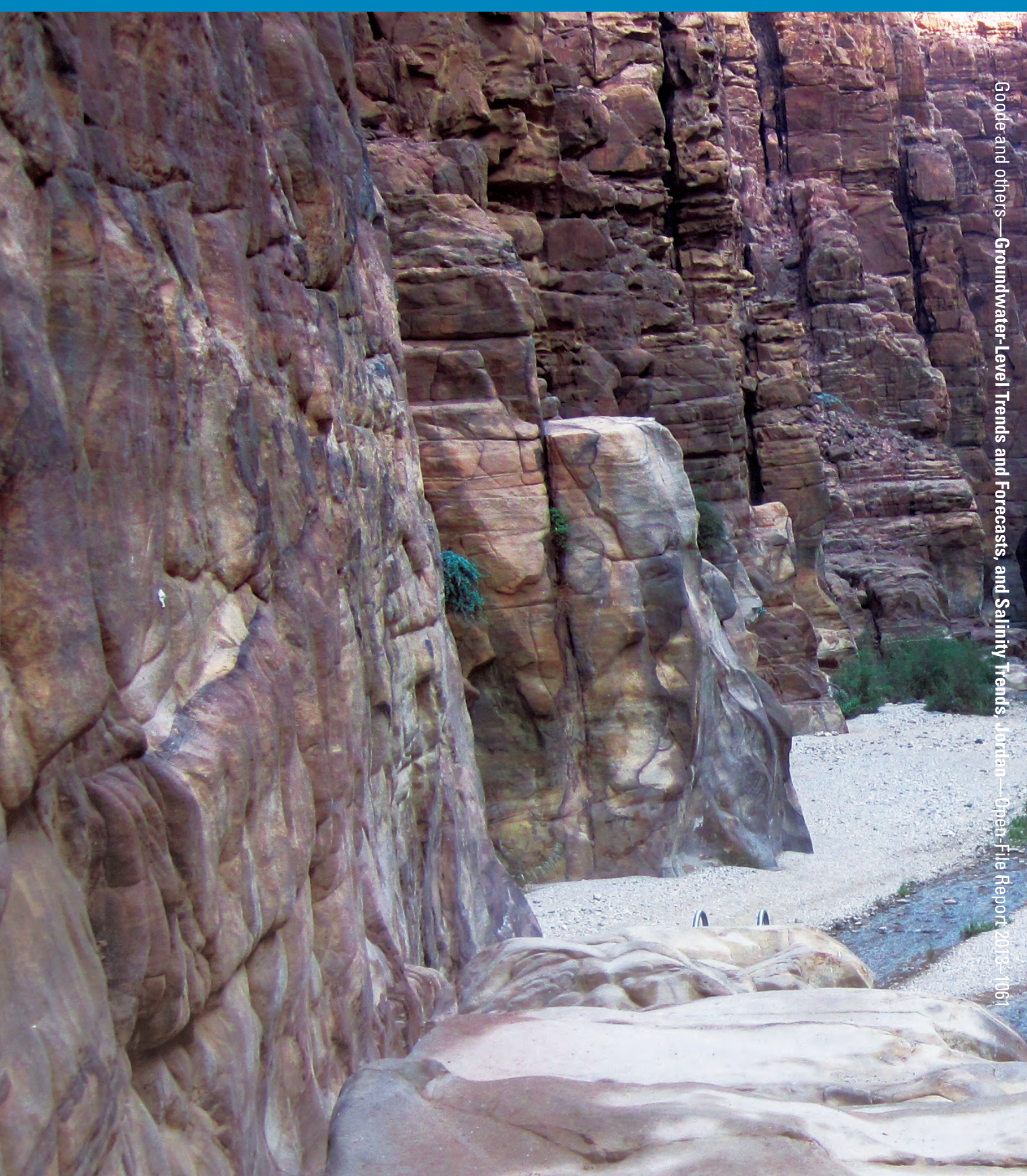

